\title{
Antibiotic resistances and plasmids in Staphylococcus aureus from Italian hospitals
}

\author{
M. GELMI, I. FORESTI, G. RAVIZZOLA, C. BONFANTI, R. VERARDI,
} A. CARUSO and A. TURANO

Institute of Microbiology, University of Brescia Spedali Civili, 25100 Brescia, Italy

\begin{abstract}
Summary. A total of 473 Staphylococcus aureus isolates from six Italian hospitals was examined for susceptibility to several antimicrobial agents and for plasmid content. Methicillin-resistant $S$. aureus (MRSA) were characterised by a plasmid of mol. wt $\left(10^{6}\right) 18-22$ or 25 that carried the determinants for penicillinase production, resistance to cadmium ions and resistance to tetracycline. MRSA isolates usually harboured other smaller plasmids of mol. wt $\left(10^{6}\right) 2.8,2.6$ and 1.65 that encoded resistance to tetracycline, chloramphenicol and erythromycin, respectively, and cryptic plasmids of mol. wt $\left(10^{6}\right) c .2$ and 1 were found frequently. Methicillin-sensitive $S$. aureus (MSSA) that produced penicillinase often carried plasmids of mol. wt $\left(10^{6}\right) 11$ or 13 . No particular difference was found in plasmid patterns of strains from the various sources. Analysis of plasmids by EcoRI digestion showed that plasmids of similar mol. wt and phenotypic characteristics may have different restriction patterns, but often share one or more fragments in common.
\end{abstract}

\section{Introduction}

Staphylococcus aureus strains frequently cause nosocomial outbreaks of infection (Lyon et al., 1983; Lacey et al., 1984). The severity of infections depends on the ability of these micro-organisms to adapt to the presence of antimicrobial drugs and to accumulate antibiotic-resistance characters (Lacey, 1975). The incidence of antibiotic resistance in $S$. aureus increased progressively in the 1960s and 1970s (Lacey et al., 1984). It has been demonstrated that the introduction of each new antimicrobial agent has been followed by the appearance and rapid spread of resistant strains of $S$. aureus (Shanson, 1981). Vancomycin and teicoplanin seem to be the only antibiotics against which resistance is unknown (Kirby, 1984).

$S$. aureus strains resistant to methicillin (MRSA) and to a series of other antibiotics have re-emerged since the mid-1970s and caused serious clinical problems in hospitals in several countries that include USA (Wenzel, 1982), Australia (Lyon et al., 1983), Greece (Giamarellou et al., 1981) and Ireland (Dowd et al., 1983). In Italy, MRSA strains responsible for nosocomial infections are isolated frequently (Andreoni et al., 1985; Schito, 1985).

Since 1983, S. aureus isolates from the Spedali Civili of Brescia have been examined for suscepti-

Received 9 Dec. 1985; revised version accepted 27 Jun. 1986. bility to antimicrobial agents and for the presence of plasmids. Recently, $S$. aureus isolates from hospitals in five other Italian towns have been investigated to determine whether their plasmids were similar and to survey the spread of the resistance determinants in Italy.

\section{Materials and methods}

\section{Bacterial strains}

The strains were collected and identified as $S$. aureus at the Laboratory of Microbiology of the Spedali Civili of Brescia on the basis of Gram's stain, colony morphology, production of coagulase and fermentation of mannitol (Baird-Parker et al., 1976). The isolates were stored in glycerol $15 \% \mathrm{v} / \mathrm{v}$ at $-70^{\circ} \mathrm{C}$.

A total of 418 clinical isolates was obtained from different patients in various units-intensive care $(27 \%)$, surgical $(31 \%)$, burns and plastic surgery $(9 \%)$, medical $(17 \%)$ and infectious diseases $(16 \%)$ - of the Spedali Civili of Brescia during the period Sep. 1983-Apr. 1985. Strains were isolated from: blood $(30.4 \%)$; wound swabs, pus and secretions $(34.8 \%)$; cerebrospinal fluid $(1.2 \%)$; pleural fluid $(3.7 \%)$; peritoneal fluid $(3.1 \%)$; bronchial secretions $(8.7 \%)$; bile $(3.1 \%)$; other materials $(15 \%)$.

Further $S$. aureus strains were kindly provided by: Professor C. Chezzi, Institute of Microbiology, Ospedale Maggiore, Parma (17 strains); Professor A. Guarino, Hospital of Avellino (9 strains); Professor G. Satta, Institute of Microbiology of Cagliari (10 strains); Professor A. La Manna, Institute of Microbiology of Firenze 
(10 strains); Professor P. Martinetto, Institute of Microbiology of Torino ( 9 strains).

S. aureus strains carrying the plasmids pII 147, pI 258 and $\mathrm{Rw} 8$, used as mol.-wt standards, were kindly provided by Dr K. Wachsmuth, Centers for Disease Control, Atlanta, GA, USA.

\section{Chemicals and antibiotics}

Chemicals were obtained from Sigma Chemicals Co., P.O. Box 14508, St Louis, MO., 63178 USA. Antibiotics and other inhibitors were obtained from Sigma except for amikacin, which was from Bristol Italiana (Sermoneta, Latina, Italy).

Antibiotic susceptibility tests were performed by the Kirby Bauer method (Bauer et al., 1966), with MuellerHinton agar plates (BBL Microbiology Systems, Cockeysville, MD, USA) and Oxoid disks (Oxoid, Basingstoke, Hampshire) containing the following antibiotics: benzylpenicillin 10 units, tetracycline $30 \mu \mathrm{g}$, erythromycin $15 \mu \mathrm{g}$, amikacin $30 \mu \mathrm{g}$, gentamicin $10 \mu \mathrm{g}$, chloramphenicol $30 \mu \mathrm{g}$, trimethoprim $1.25 \mu \mathrm{g}$, sulphamethoxazole $25 \mu \mathrm{g}$, ampicillin $10 \mu \mathrm{g}$, methicillin $5 \mu \mathrm{g}$, cefotaxime $30 \mu \mathrm{g}$, cephalexin $30 \mu \mathrm{g}$, rifampicin $30 \mu \mathrm{g}$; vancomycin $30 \mu \mathrm{g}$, streptomycin $10 \mu \mathrm{g}$.

Susceptibility to cadmium ions was tested by disk diffusion on Mueller-Hinton agar plates with paper disks impregnated with $20 \mu \mathrm{l}$ of a $0 \cdot 01 \mathrm{M}$ solution of cadmium sulphate.

The disk susceptibility tests were performed with an inoculum of $c .10^{4} \mathrm{cfu}$ from an overnight culture.

Minimum inhibitory concentrations (MICs) were determined by the Sceptor System (BBL Microbiology Systems, Becton Dickinson) for the following antibiotics: methicillin $(0.25-8 \mathrm{mg} / \mathrm{L})$, penicillin $(0.12-16 \mathrm{mg} / \mathrm{L})$, ampicillin $(0.25-16 \mathrm{mg} / \mathrm{L})$, cephalothin $(0.5-32 \mathrm{mg} / \mathrm{L})$, amikacin $(0.5-32 \mathrm{mg} / \mathrm{L})$, gentamicin $(0.12-8 \mathrm{mg} / \mathrm{L})$, clindamycin $(0 \cdot 12-8 \mathrm{mg} / \mathrm{L})$, erythromycin $(0 \cdot 12-8 \mathrm{mg} / \mathrm{L})$, tetracycline $(0.5-32 \mathrm{mg} / \mathrm{L})$, chlorampenicol $(0.5-32 \mathrm{mg} /$ $\mathrm{L})$, vancomycin $(0.25-16 \mathrm{mg} / \mathrm{L})$, trimethoprim/sulphamethoxazole $(0 \cdot 5 / 9 \cdot 5-16 / 304 \mathrm{mg} / \mathrm{L})$. The Sceptor System was also used to detect penicillinase production.

For multiresistant strains, MICs were determined also by the broth dilution, technique (Mueller-Hinton broth, BBL) at the following drug concentrations $(\mathrm{mg} / \mathrm{L})$ : amikacin, kanamycin, tobramycin, gentamicin, streptomycin, tetracycline, chloramphenicol, benzylpenicillin, ampicillin (16-256); and methicillin, cephalothin, erythromycin (2-64).

For the sensitivity testing an inoculum of $c .10^{4} \mathrm{cfu} / \mathrm{ml}$ was used.

\section{Isolation of plasmid DNA}

Initially, plasmid DNA was isolated by a modification of the Birnboim procedure (Birnboim and Doly, 1979). The cells, grown overnight in Luria Bertani broth (Bacto
Tryptone $1 \%$, Bacto Yeast extract $0.5 \%, \mathrm{NaCl} 1 \%, p \mathrm{H}$ 7.5 ), were harvested by centrifugation of $0.5 \mathrm{ml}$ of broth culture at $10000 \mathrm{~g}$ for $1 \mathrm{~min}$ (Eppendorf centrifuge 5412) and resuspended in $100 \mu \mathrm{l}$ of the following lytic solution: lysostaphin (Sigma) $20 \mathrm{mg} / \mathrm{L}$ in $50 \mathrm{~mm}$ glucose, $25 \mathrm{~mm}$ Tris $\mathrm{HCl}, 10 \mathrm{~mm}$ EDTA $p \mathrm{H} 8$. Tubes were incubated at $37^{\circ} \mathrm{C}$ for $45 \mathrm{~min}$. Lysis was achieved by adding $200 \mu \mathrm{l}$ of sodium dodecyl sulphate $1 \%$ in $0 \cdot 2 \mathrm{~N} \mathrm{NaOH}$, incubating at $0^{\circ} \mathrm{C}$ for $5 \mathrm{~min}$ and then adding $150 \mu \mathrm{l}$ of $3 \mathrm{M}$ sodium acetate $(p \mathrm{H} \mathrm{4} \cdot 8)$. The lysates were incubated at $0^{\circ} \mathrm{C}$ for at least $60 \mathrm{~min}$ and then centrifuged at $10000 \mathrm{~g}$ for $7 \mathrm{~min}$. Cold ethanol $(1 \mathrm{ml})$ was added to the supernate and tubes were kept at $-70^{\circ} \mathrm{C}$ for $30 \mathrm{~min}$. After centrifugation at $10000 \mathrm{~g}$ for $8 \mathrm{~min}$, the precipitate that contained the plasmid DNA was resuspended in $100 \mu \mathrm{l}$ of $0 \cdot 1 \mathrm{M}$ sodium acetate, $0.05 \mathrm{M}$ Tris $\mathrm{HCl}(p \mathrm{H} \mathrm{8})$. A $200 \mu$ l volume of ethanol was added to the DNA preparation and the tubes were held at $-70^{\circ} \mathrm{C}$ for $30 \mathrm{~min}$. The final pellet obtained by centrifugation at $10000 \mathrm{~g}$ for $8 \mathrm{~min}$, was resuspended in $10 \mathrm{~mm}$ Tris $\mathrm{HCl}, 1 \mathrm{~mm}$ EDTA ( $p \mathrm{H} 8)$.

Recently, we have extracted the plasmid DNA by the more rapid method of Dunkle and Sippell (1984).

Samples were electrophoresed in agarose gel $0.75 \%$ in TPE $(0.08 \mathrm{M}$ phosphate Tris, $0.002 \mathrm{M}$ EDTA) in a horizontal gel electrophoresis system (BRL, mod. H4) for $14 \mathrm{~h}$ at $20 \mathrm{~V}$ at room temperature.

\section{Restriction enzyme analysis}

Plasmid DNA was cut with EcoRI according to the manufacturer's directions (BRL lyphozyme; Bethesda Research Laboratories, Gainthersburg, MD, 20760, USA). Phage lambda DNA (BRL) was used as a control and the fragments separated by electrophoresis in agarose gel $0.75 \%$ in TPE for $14 \mathrm{~h}$ at $20 \mathrm{~V}$ at room temperature.

\section{Curing experiments}

Plasmids were eliminated by growth in Luria-Bertani broth for $18-24 \mathrm{~h}$ at $44^{\circ} \mathrm{C}$ (Asheshov, 1966) or by growth at $37^{\circ} \mathrm{C}$ in presence of ethidium bromide or acridine orange at various concentrations. (Bouanchaud et al., 1968).

\section{Results}

Resistance to antimicrobial agents of strains isolated from Brescia Hospital

More than $60 \%$ of 418 isolates tested between Sep. 1983 and Apr. 1985 were found to be multiresistant (table I). The large number of such isolates was probably due to the widespread 
Table I. Patterns of antibiotic resistance in isolates of $S$. aureus from Brescia

\begin{tabular}{|c|c|c|c|}
\hline \multirow[b]{2}{*}{ Resistance pattern } & \multicolumn{3}{|c|}{$\begin{array}{l}\text { Percentage of Staph. aureus } \\
\text { isolates collected during } \\
\text { (number of isolates) }\end{array}$} \\
\hline & $\begin{array}{c}\text { Sept.-Dec. } \\
1983(87)\end{array}$ & $\begin{array}{l}\text { Jan.-Dec. } \\
1984 \text { (202) }\end{array}$ & $\begin{array}{l}\text { Jan.-Apr. } \\
1985 \text { (129) }\end{array}$ \\
\hline None & $11 \cdot 5$ & $13 \cdot 3$ & $19 \cdot 3$ \\
\hline Penicillin & $6 \cdot 9$ & $17 \cdot 1$ & $14 \cdot 7$ \\
\hline $\begin{array}{l}\text { Penicillin-tetracycline } \\
\text { or } \\
\text { Penicillin-erythromycin }\end{array}$ & $4 \cdot 6$ & $5 \cdot 0$ & $1 \cdot 7$ \\
\hline Multiple (MRSA) & $77 \cdot 0$ & $64 \cdot 6$ & $64 \cdot 3$ \\
\hline
\end{tabular}

dissemination of a few strains responsible for nosocomial epidemics during the period of study. During the same period an increasing frequency of isolation of $S$. aureus susceptible to all the tested drugs or resistant to penicillin only, can be seen (table I).

The multiresistant isolates had similar resistance patterns; they were resistant to: methicillin (MIC $>64 \mathrm{mg} / \mathrm{L})$, penicillin $(>256 \mathrm{mg} / \mathrm{L})$, gentamicin $(>256 \mathrm{mg} / \mathrm{L})$, tetracycline $(>256 \mathrm{mg} / \mathrm{L})$, erythromycin (>64 mg/L), rifampicin, streptomycin and sulphamethoxazole (MICs not determined). Susceptibility to amikacin, netilmicin, chloramphenicol and trimethoprim were variable but all the isolates tested were susceptible to vancomycin (MIC $1 \mathrm{mg} / \mathrm{L}$ ). About $70 \%$ of MRSA strains were resistant to cadmium ions.

On the basis of the resistance patterns and plasmid profiles (see below) of the MRSA isolates, it was possible to observe that nosocomial infections were caused mainly by two distinct strains. These strains were isolated, with great frequency from patients undergoing antibiotic therapy, in the intensive care and burns and plastic surgery units. The incidence of multiresistant strains was lower in other units.

\section{Plasmid profiles of strains isolated from Brescia Hospital}

Plasmids and resistance phenotype have been correlated by curing experiments. The isolated plasmids have been labelled for convenience. Among the isolates examined, those susceptible to all antibiotics did not contain plasmids, except three strains in which a cryptic plasmid of mol. wt $\left(10^{6}\right)$ c. 2 (pBS4384) was found (fig. 1, lane A).

Isolates resistant to penicillin and susceptible to all the other antibiotics were frequent. Such isolates

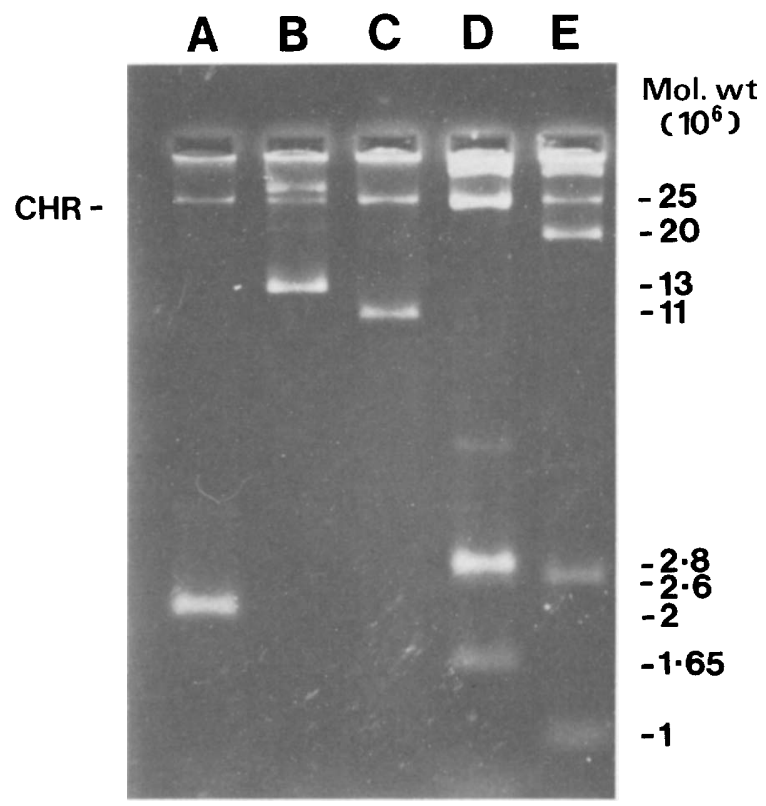

Fig. 1. Plasmid patterns of $S$. aureus isolated in Brescia. Lanes A, B and C show the profiles of MSSA strains, lanes D and E show the profiles of MRSA strains. A : plasmid pBS4384; B: pBS1884; C: pBS3583; D: pBS283, pBS3784, pBS2585, pBS4985; E: pBS983, pBS2585, pBS1285. Plasmid mol. wts $\left(10^{6}\right)$ are shown on the right. $\mathrm{CHR}=$ chromosomal DNA.

harboured only one plasmid of mol. wt $\left(10^{6}\right) 13$ (pBS1884) or 11 (pBS3583) (fig. 1, lanes B and C). Plasmid pBS1884 confers resistance to penicillin and to cadmium ions; pBS3583 encodes only penicillinase production. In some penicillin-resistant isolates no plasmid DNA was found.

$S$. aureus strains resistant to penicillin and to tetracycline or erythromycin have been isolated occasionally. These strains carried a plasmid of mol. wt $11 \times 10^{6}$, identical to pBS3583, and a smaller plasmid of mol. wt $2.8 \times 10^{6}$ in tetracyclineresistant isolates and $1.65 \times 10^{6}$ in the erythromycin-resistant isolates.

Each MRSA isolate contained between 1-4 plasmids, but most showed a uniform plasmid profile of four plasmids of mol. wt $\left(10^{6}\right)$ c. 25 (pBS283), 2.8 (pBS3784), 2.6 (pBS2585) and 1.65 (pBS4985) (fig. 1, lane D). Curing experiments indicated that plasmid pBS283 encodes penicillinase production, resistance to cadmium ions and resistance to tetracycline; pBS3784 confers resistance to tetracycline; pBS2585 carries the determinant for chloramphenicol resistance and pBS4985 is responsible for erythromycin resistance. Isolates that lost the plasmid pBS3784 retained tetracycline resistance and only the simultaneous elimination of both pBS283 and pBS3784 caused loss of the 
resistant phenotype. In these isolates, therefore, the determinant for tetracycline resistance appeared to be present on two different plasmids.

Other resistances in these isolates (streptomycin, gentamicin, amikacin, methicillin, cefotaxime, cephalexin, sulphamethoxazole and rifampicin) were encoded by chromosomal genes.

Other MRSA strains isolated frequently carried three plasmids of mol. wt $\left(10^{6}\right)$ c. 20 (pBS983), $2 \cdot 6$ (this plasmid confers chloramphenicol resistance and it was considered to be identical to pBS2585), and 1 (pBS1285) (fig. 1, lane E). Plasmid pBS983 encoded resistance to penicillin and tetracycline; pBS1285 remained cryptic. In these isolates, the resistances to gentamicin, methicillin, erythromycin, trimethoprim, sulphamethoxazole, rifampicin and streptomycin were chromosomally encoded.

Recently, multiresistant strains totally devoid of plasmids have been isolated, suggesting that all the resistance determinants in these strains are integrated into the chromosome.

Characteristics of the plasmids isolated in Brescia are listed in table II.

\section{Antibiotic resistances and plasmid profiles of isolates from five other Italian towns}

The isolates received from the other Italian hospitals had the resistance characteristics and plasmids shown in table III.

MRSA strains showed similar plasmid patterns to those found in MRSA strains from Brescia. A plasmid of mol. wt $\left(10^{6}\right)$ c. 25 or 18-22 was always present, conferring various resistance phenotypes (table III). Smaller plasmids of mol. wt $\left(10^{6}\right) 2 \cdot 8$, 2.6 and 1.65 , encoding resistance to tetracycline, chloramphenicol and erythromycin respectively, could also be found.

Methicillin-susceptible isolates that were resistant to penicillin harboured plasmids of mol. wt $\left(10^{6}\right) 11,13$ or 18 . The plasmids of mol. wt $\left(10^{6}\right) 11$ and 13 were similar to pBS3583 and pBS1884; the $18 \times 10^{6}$-mol.wt plasmid was found only in one isolate from Cagliari.

\section{Restriction enzyme analysis}

The relationship between isolated plasmids was verified by $E c o$ RI digestion, and the fragments of the plasmids isolated in Brescia (pBS283, pBS983, pBS1884, pBS3583) are shown in fig. 2 (lanes B, C, D, E).

Endonuclease digestion of pBS283, pBS983 and pBS1884 generated six, five and three fragments respectively. Digestion of pBS3583 generated only
Table II. Characteristics of plasmids in isolates from Brescia

\begin{tabular}{|c|c|c|}
\hline Plasmid & $\begin{array}{l}\text { Mol.wt } \\
\left(10^{6}\right)\end{array}$ & Resistance phenotype \\
\hline pBS283 & c. 25 & penicillin-tetracycline-cadmium \\
\hline pBS983 & c. 20 & penicillin-tetracycline \\
\hline pBS1884 & 13 & penicillin-cadmium \\
\hline pBS3583 & 11 & penicillin \\
\hline pBS3784 & $2 \cdot 8$ & tetracycline \\
\hline pBS2585 & $2 \cdot 6$ & chloramphenicol \\
\hline pBS4384 & 2 & cryptic \\
\hline pBS4985 & $1 \cdot 65$ & erythromycin \\
\hline pBS1285 & 1 & cryptic \\
\hline
\end{tabular}

one fragment that migrated more slowly than the unrestricted plasmid.

Treatment of pBS3784, pBS2585, pBS4384, pBS4985 and pBS1285 with EcoRI generated two bands that probably corresponded to the open circular and covalently-closed circular forms (data not shown).

The plasmids pBS283 and pBS983 shared three EcoRI fragments of about $7 \cdot 3,4.5$ and $3.2 \mathrm{~Kb}$. These fragments were also obtained from plasmid pII 147 (fig. 2, lane F); pBS283 also shared with pII 147 a fourth fragment of about $6.8 \mathrm{~Kb}$.

Restriction analysis of some plasmids isolated in the other towns showed fragment patterns identical to the ones isolated in Brescia. In particular, plasmids of mol. wt $25 \times 10^{6}$, harboured by isolates from all the towns, except Avellino, shared all the EcoRI fragments with pBS283. One isolate from Firenze (FI 6) carried a $25 \times 10^{6}-\mathrm{mol}$. wt plasmid with a different restriction pattern; it showed the absence of the $6 \cdot 8-\mathrm{Kb}$ fragment and the presence of additional smaller fragments (fig. 2, lane G). This plasmid, however, conferred the same resistance characteristics as pBS283.

A greater variety of restriction patterns emerged in the $(18-22) \times 10^{6}$-mol. wt plasmids (fig. 2, lanes $\mathrm{H}, \mathbf{I}, \mathbf{J}, \mathbf{K}, \mathrm{L}, \mathrm{M})$.

Plasmids with an EcoRI digestion profile identical to pBS983 were found in isolates from all the towns, except Avellino. Isolates from Avellino (AV 3-5-7) harboured a $20 \times 10^{6}-\mathrm{mol}$. wt plasmid with the same restriction pattern as that present in isolates from Parma (PR 12-13-15) (fig. 2, lane K) and Cagliari (CA 2) (fig. 2, lane H). These plasmids shared two EcoRI fragments with pBS283.

Restriction endonuclease digestion of the $22 \times$ $10^{6}$-mol. wt plasmid carried by the isolate PR 3 produced a series of fragments, three of which were common to pBS283 (fig. 2, lane I). The restriction patterns of the $22 \times 10^{6}-\mathrm{mol}$. wt plasmid isolated 
Table III. Characteristics of isolates from five other Italian towns

\begin{tabular}{|c|c|c|c|c|c|c|c|c|c|c|c|}
\hline \multirow{2}{*}{$\begin{array}{l}\text { Isolates (number } \\
\text { per centre) }\end{array}$} & \multicolumn{10}{|c|}{ Resistance profile of isolates } & \multirow{2}{*}{$\begin{array}{l}\text { Plasmid mol. wt }\left(10^{6}\right) \\
\text { (associated phenotype) }\end{array}$} \\
\hline & Met & Pen & $\mathrm{Ak}$ & $\mathrm{Gm}$ & $\mathrm{Cm}$ & Tc & Em & Sxt & $\mathrm{Rf}$ & $\mathrm{Va}$ & \\
\hline \multicolumn{12}{|l|}{ Parma (17) } \\
\hline PR 1 & $\mathbf{R}$ & $\mathbf{R}$ & $\mathbf{S}$ & $\mathbf{R}$ & $\mathbf{S}$ & $\mathbf{R}$ & $\mathbf{R}$ & $\mathbf{R}$ & $\mathbf{R}$ & $\mathbf{S}$ & 20 (Pen-Tc); 1 (cry) \\
\hline PR 3 & $\mathrm{R}$ & $\mathbf{R}$ & $\mathbf{S}$ & $\mathbf{R}$ & $\mathbf{S}$ & $\mathbf{S}$ & $\mathbf{R}$ & $\mathrm{S}$ & $\mathbf{R}$ & $\mathbf{S}$ & 22 (Pen-Gm); 1 (cry) \\
\hline $\begin{array}{r}\text { PR } 6-7-8 \\
14-18\end{array}$ & $\mathbf{R}$ & $\mathbf{R}$ & $\mathbf{R}$ & $\mathbf{R}$ & $\mathrm{S}$ & $\mathbf{R}$ & $\mathbf{R}$ & $\mathbf{S}$ & $\mathbf{R}$ & $\mathrm{S}$ & $\begin{array}{l}22(\text { Pen-Tc-Gm) } \\
1.65(\mathrm{Em})\end{array}$ \\
\hline PR 4 & $\mathbf{R}$ & $\mathbf{R}$ & $\mathbf{R}$ & $\mathbf{R}$ & $\mathbf{S}$ & $\mathbf{R}$ & $\mathbf{R}$ & $\mathbf{S}$ & $\mathbf{R}$ & $\mathrm{S}$ & $25(\mathrm{Pen}-\mathrm{Tc}-\mathrm{Cd}) ; 1.65(\mathrm{Em})$ \\
\hline PR 5 & $\mathbf{R}$ & $\mathbf{R}$ & $\mathbf{S}$ & $\mathbf{R}$ & $\mathbf{R}$ & $\mathbf{R}$ & $\mathbf{R}$ & $\mathbf{R}$ & $\mathbf{R}$ & $\mathbf{S}$ & $20($ Pen-Tc); $2.6(\mathrm{Cm})$ \\
\hline $\begin{array}{c}\text { PR } 12-13 \\
15\end{array}$ & $\mathbf{R}$ & $\mathbf{R}$ & $\mathbf{R}$ & $\mathbf{R}$ & $\mathbf{S}$ & $\mathbf{S}$ & $\mathbf{R}$ & $\mathbf{S}$ & $\mathrm{S}$ & $\mathrm{S}$ & $20($ Pen-Gm) \\
\hline PR 10 & $\mathbf{S}$ & $\mathbf{S}$ & $\mathbf{S}$ & $\mathbf{S}$ & $\mathbf{S}$ & $\mathbf{S}$ & $\mathbf{S}$ & $\mathbf{S}$ & $\mathbf{S}$ & $\mathbf{S}$ & 2 (cry) \\
\hline PR 11 & $\mathbf{S}$ & $\mathbf{S}$ & $\mathbf{S}$ & $\mathbf{S}$ & $\mathbf{R}$ & $\mathbf{S}$ & $\mathbf{R}$ & $\mathbf{S}$ & $\mathbf{S}$ & $\mathbf{S}$ & $2.6(\mathrm{Cm}) ; 1.65(\mathrm{Em})$ \\
\hline PR 9-17 & $\mathbf{S}$ & $\mathbf{R}$ & $\mathbf{S}$ & $\mathbf{S}$ & $\mathrm{S}$ & $\mathbf{S}$ & $\mathrm{S}$ & $\mathbf{S}$ & $\mathbf{S}$ & $\mathbf{S}$ & 11 (Pen) \\
\hline PR 16 & $\mathrm{~S}$ & $\mathbf{R}$ & $\mathrm{S}$ & $\mathbf{S}$ & $\mathrm{S}$ & $\mathrm{S}$ & $\mathrm{S}$ & $\mathbf{S}$ & $\mathrm{S}$ & $\mathbf{S}$ & no plasmid \\
\hline \multicolumn{12}{|l|}{ Cagliari (10) } \\
\hline $\mathrm{CA} 2$ & $\mathbf{R}$ & $\mathbf{R}$ & $\mathbf{S}$ & $\mathbf{R}$ & $\mathrm{S}$ & $\mathbf{S}$ & $\mathrm{R}$ & $\mathbf{S}$ & $\mathrm{S}$ & $\mathbf{S}$ & $20($ Pen-Gm) \\
\hline CA 6 & $\mathbf{R}$ & $\mathbf{R}$ & $\mathbf{S}$ & $\mathbf{R}$ & $\mathbf{S}$ & $\mathbf{R}$ & $\mathbf{R}$ & $\mathbf{R}$ & $\mathbf{R}$ & $\mathrm{S}$ & 20 (Pen-Tc); 1 (cry) \\
\hline CA 9 & $\mathbf{R}$ & $\mathbf{R}$ & $\mathrm{S}$ & $\mathbf{R}$ & $\mathrm{S}$ & $\mathbf{R}$ & $\mathbf{R}$ & $\mathrm{S}$ & $\mathrm{S}$ & $\mathrm{S}$ & $25($ Pen-Tc-Cd) \\
\hline CA 1 & $\mathrm{~S}$ & $\mathbf{R}$ & $\mathbf{S}$ & $\mathbf{S}$ & $\mathbf{S}$ & $\mathbf{S}$ & $\mathbf{S}$ & $\mathrm{S}$ & $\mathrm{S}$ & $\mathrm{S}$ & 11 (Pen) \\
\hline CA $3-10$ & $\mathbf{S}$ & $\mathbf{R}$ & $\mathrm{S}$ & $\mathbf{S}$ & $S$ & $S$ & $\mathrm{~S}$ & $\mathbf{S}$ & $\mathrm{S}$ & $\mathrm{S}$ & 18 (Pen) \\
\hline CA 4 & $\mathrm{~S}$ & $\mathbf{R}$ & $\mathbf{S}$ & $\mathbf{S}$ & $\mathbf{S}$ & $\mathbf{S}$ & $\mathrm{S}$ & $\mathbf{S}$ & $\mathbf{S}$ & $S$ & no plasmid \\
\hline CA $7-8$ & $\mathrm{~S}$ & $\mathbf{R}$ & $\mathrm{S}$ & $\mathbf{S}$ & $\mathrm{S}$ & $\mathbf{R}$ & $\mathrm{S}$ & $\mathrm{S}$ & $\mathrm{S}$ & $\mathbf{S}$ & $13($ Pen-Cd); $2.8(\mathrm{Tc})$ \\
\hline CA 5 & $\mathbf{S}$ & $\mathbf{S}$ & $\mathbf{S}$ & $\mathbf{S}$ & $\mathbf{S}$ & $\mathbf{S}$ & $\mathbf{S}$ & $\mathbf{S}$ & $\mathbf{S}$ & $\mathbf{S}$ & 2 (cry) \\
\hline \multicolumn{12}{|l|}{ Avellino (9) } \\
\hline AV 3-5-7 & $\mathbf{R}$ & $\mathbf{R}$ & $\mathbf{S}$ & $\mathbf{R}$ & $\mathbf{S}$ & $\mathbf{R}$ & $\mathbf{R}$ & $\mathbf{S}$ & $\mathbf{S}$ & $\mathrm{S}$ & $20($ Pen-Gm); $2.8(\mathrm{Tc})$ \\
\hline AV 1 & $\mathbf{S}$ & $\mathbf{R}$ & $\mathbf{S}$ & $\mathbf{S}$ & $\mathbf{S}$ & $S$ & $\mathrm{~S}$ & $\mathbf{S}$ & $S$ & $S$ & $13($ Pen-Cd) \\
\hline AV 6-12 & $\mathrm{S}$ & $\mathbf{R}$ & $\mathrm{S}$ & $\mathrm{S}$ & $\mathrm{S}$ & $\mathbf{S}$ & $\mathrm{S}$ & $\mathbf{S}$ & $\mathrm{S}$ & $\mathrm{S}$ & no plasmid \\
\hline AV 10 & $\mathbf{S}$ & $\mathrm{S}$ & $S$ & $\mathbf{R}$ & $S$ & $\mathrm{~S}$ & $\mathrm{~S}$ & $\mathbf{S}$ & $\mathrm{S}$ & $\mathrm{S}$ & no plasmid \\
\hline AV 2-13 & $\mathrm{S}$ & $\mathrm{S}$ & $\mathrm{S}$ & $\mathrm{S}$ & $\mathrm{S}$ & $\mathbf{S}$ & $\mathrm{S}$ & $\mathbf{S}$ & $\mathrm{S}$ & $\mathbf{S}$ & 2 (cry) \\
\hline \multicolumn{12}{|l|}{ Firenze (10) } \\
\hline FI 1 & $\mathbf{R}$ & $\mathbf{R}$ & $\mathbf{S}$ & $\mathbf{R}$ & $\mathbf{R}$ & $\mathbf{R}$ & $\mathbf{R}$ & $\mathrm{S}$ & $\mathrm{S}$ & $\mathrm{S}$ & $25($ Pen-Tc-Cd $) ; 2.6(\mathrm{Cm})$ \\
\hline FI 2-8 & $\mathbf{R}$ & $\mathbf{R}$ & $\mathbf{S}$ & $\mathbf{R}$ & $\mathrm{S}$ & $\mathbf{R}$ & $\mathbf{R}$ & $\mathbf{S}$ & $\mathrm{R}$ & $S$ & $25($ Pen-Tc-Cd); $2.8(\mathrm{Tc})$ \\
\hline FI 4-9 & $\mathbf{R}$ & $\mathbf{R}$ & $\mathbf{S}$ & $\mathbf{R}$ & $\mathrm{S}$ & $\mathbf{R}$ & $\mathbf{R}$ & $\mathrm{S}$ & $\mathbf{R}$ & $\mathrm{S}$ & $\begin{array}{l}25(\mathrm{Pen}-\mathrm{Tc}-\mathrm{Cd}) ; 2.8(\mathrm{Tc}) \\
1.65(\mathrm{Em})\end{array}$ \\
\hline FI 3 & $\mathbf{R}$ & $\mathbf{R}$ & $\mathbf{R}$ & $\mathbf{R}$ & $\mathbf{S}$ & $\mathbf{R}$ & $\mathbf{R}$ & $\mathbf{R}$ & $\mathrm{R}$ & $S$ & $20($ Pen-Tc) $; 1.65(\mathrm{Em})$ \\
\hline FI 5-10 & $\mathbf{R}$ & $\mathbf{R}$ & $\mathbf{R}$ & $\mathbf{R}$ & $\mathbf{S}$ & $\mathbf{R}$ & $\mathbf{R}$ & $\mathbf{S}$ & $\mathbf{R}$ & $\mathbf{S}$ & $\begin{array}{l}25(\mathrm{Pen}-\mathrm{Tc}-\mathrm{Cd}) ; 1.65(\mathrm{Em}) \\
2 \text { (cry); } 2.8(\mathrm{Tc})\end{array}$ \\
\hline FI 6 & $\mathbf{R}$ & $\mathbf{R}$ & $\mathbf{R}$ & $\mathbf{R}$ & $\mathbf{R}$ & $\mathbf{R}$ & $\mathbf{R}$ & $\mathbf{R}$ & $\mathbf{R}$ & $\mathbf{S}$ & $\begin{array}{l}25(\text { Pen-Tc-Cd }) ; 1.65(\mathrm{Em}) \\
2.6(\mathrm{Cm}) ; 1 \text { (cry) }\end{array}$ \\
\hline FI 7 & $\mathbf{R}$ & $\mathbf{R}$ & $\mathbf{R}$ & $\mathbf{R}$ & $\mathbf{S}$ & $\mathbf{R}$ & $\mathbf{R}$ & $\mathbf{R}$ & $\mathbf{R}$ & $\mathbf{S}$ & $20(\operatorname{Pen}-\mathrm{Tc})$ \\
\hline \multicolumn{12}{|l|}{ Torino (9) } \\
\hline TO 1 & $\mathbf{R}$ & $\mathbf{R}$ & $\mathbf{S}$ & $\mathbf{R}$ & $\mathbf{S}$ & $\mathbf{R}$ & $\mathbf{R}$ & $\mathbf{S}$ & $\mathbf{R}$ & $\mathrm{S}$ & $\begin{array}{l}25(\mathrm{Pen}-\mathrm{Tc}-\mathrm{Cd}) ; 2.8(\mathrm{Tc}) \\
2 \text { (cry) }\end{array}$ \\
\hline TO 5-6-7 & $\mathbf{R}$ & $\mathbf{R}$ & $\mathbf{S}$ & $\mathbf{R}$ & $\mathrm{S}$ & $\mathbf{R}$ & $\mathbf{R}$ & $\mathrm{S}$ & $\mathbf{R}$ & $\mathrm{S}$ & $25($ Pen-Tc-Cd $)$ \\
\hline TO 2 & $\mathbf{R}$ & $\mathbf{R}$ & $\mathbf{S}$ & $\mathbf{R}$ & $\mathbf{S}$ & $\mathbf{R}$ & $\mathbf{R}$ & $\mathbf{R}$ & $\mathbf{R}$ & $\mathrm{S}$ & 20 (Pen-Tc); 1 (cry) \\
\hline TO 8 & $\mathbf{R}$ & $\mathbf{R}$ & $\mathbf{S}$ & $\mathbf{R}$ & $S$ & $\mathrm{~S}$ & $\mathbf{R}$ & $\mathbf{S}$ & $S$ & $\mathbf{S}$ & no plasmid \\
\hline TO 9 & $\mathbf{R}$ & $\mathbf{R}$ & $\mathrm{S}$ & $\mathbf{R}$ & $\mathbf{S}$ & $\mathbf{S}$ & $\mathbf{R}$ & $\mathrm{S}$ & $S$ & $S$ & $22(\operatorname{Pen}-\mathrm{Gm})$ \\
\hline TO 12 & $\mathbf{R}$ & $\mathbf{R}$ & $\mathbf{S}$ & $\mathbf{S}$ & $\mathbf{R}$ & $\mathbf{R}$ & $\mathbf{R}$ & $\mathbf{S}$ & $\mathbf{R}$ & S & $\begin{array}{l}25(\mathrm{Pen}-\mathrm{Tc}-\mathrm{Cd}) ; 1.65(\mathrm{Em}) \\
2.4(\mathrm{Cm}) ; 2.8(\mathrm{Tc})\end{array}$ \\
\hline TO 4 & $\mathbf{S}$ & $\mathbf{R}$ & $\mathrm{S}$ & $\mathrm{S}$ & $\mathrm{S}$ & $\mathbf{S}$ & $\mathrm{S}$ & $\mathbf{S}$ & $\mathrm{S}$ & $\mathrm{S}$ & no plasmid \\
\hline
\end{tabular}

Met, methicillin; Pen, penicillin; Ak, amikacin; Gm, gentamicin; Cm, chloramphenicol; Tc, tetracycline; Em, erythromycin; Sxt, trimethoprim/sulphamethoxazole; Rf, rifampicin; Va, vancomycin; Cd, cadmium ions; cry, cryptic. 


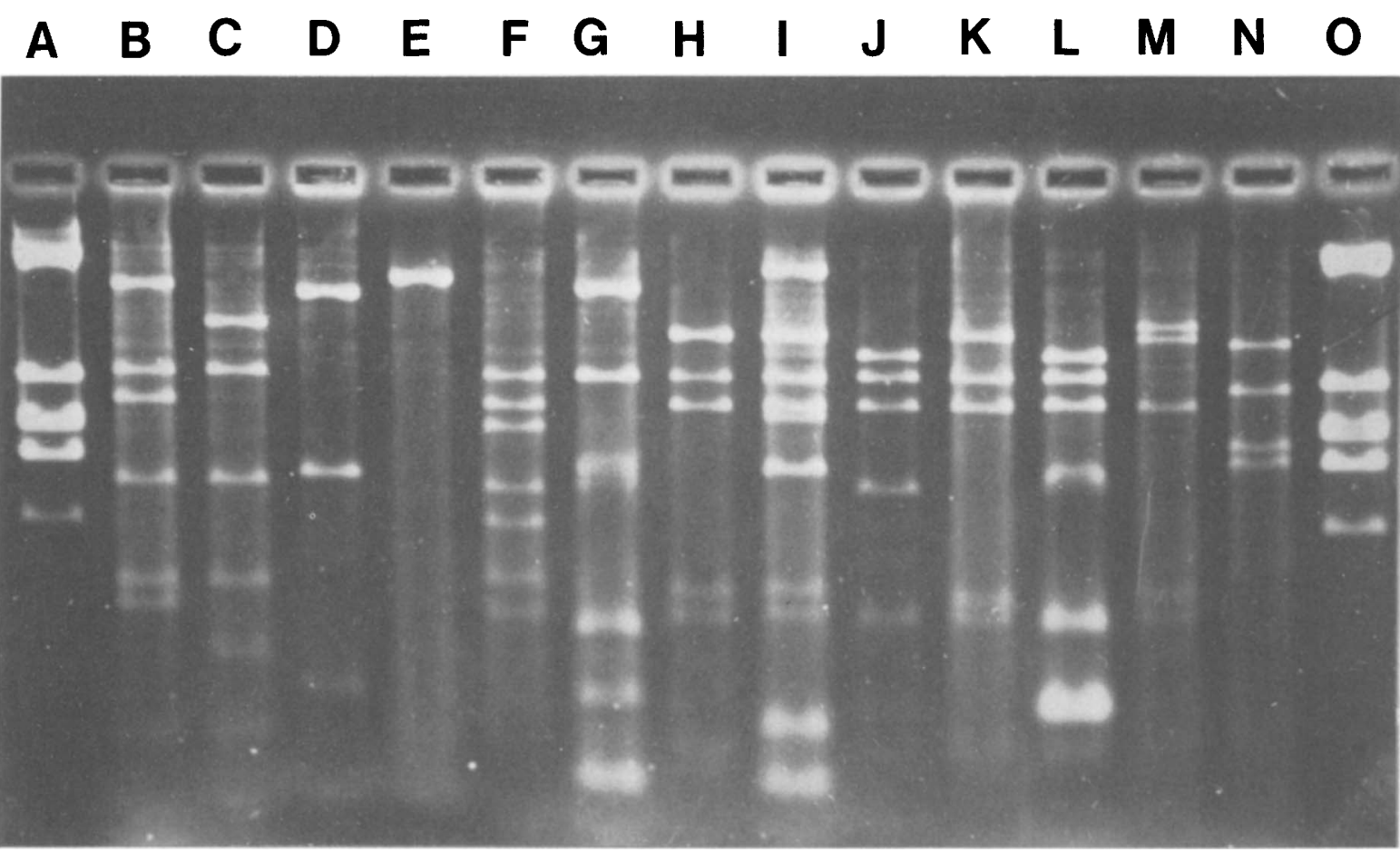

Fig. 2. EcoRI restriction digests of isolated plasmid DNA from $S$. aureus. Lanes A and O: phage lambda DNA; B: pBS283; C: pBS983; D: pBS1884; E: pBS3583; F: pII147; G : plasmids from FI6; H: plasmid from CA2; I: plasmids from PR3; J : plasmids from PR6; K : plasmid from PR13; L: plasmids from PR14; M: plasmid from TO9; N: plasmid from CA3.

from PR 6 and PR 14 strains also produced two bands common to pBS983 and pBS283 (fig. 2, lanes $\mathrm{J}$ and $\mathbf{L}$ ).

Analysis of the $22 \times 10^{6}$-mol. wt plasmid found in strain TO 9 generated three fragments, one of which was common to pBS283 (fig. 2, lane M), while plasmids of mol. wt $\left(10^{6}\right) 11$ and 13 showed patterns identical to pBS3583 and pBS1884.

The $18 \times 10^{6}-\mathrm{mol}$. wt plasmid carried by isolate CA 3, isolated in Cagliari, showed a digestion profile different from the previous ones (fig. 2, lane N).

\section{Discussion}

Methicillin-resistant and methicillin-sensitive isolates of $S$. aureus from six hospitals in different Italian towns were analysed to investigate the genetic nature and the spread of the resistance determinants. Many of the methicillin-susceptible (MSSA) isolates from the various sources produced penicillinase; generally this trait was associated with the presence of a plasmid of mol. wt $\left(10^{6}\right) 11$ or 13 but in a few strains was chromosomally encoded. Plasmids responsible for penicillinase production in MSSA were never found in MRSA.
The MRSA were characterised by a plasmid of mol. wt $\left(10^{6}\right) 18-22$ or 25 . This plasmid carried more than one resistance determinant. In the isolates from Brescia, such a plasmid always encoded penicillinase production and resistance to tetracycline (plasmid pBS983); it sometimes also encoded resistance to cadmium ions (plasmid pBS283). The plasmids of similar mol. wt present in isolates from other towns often carried the same resistance determinants but plasmids possessing different arrays of resistances were also detected. The plasmids of mol. wt $\left(10^{6}\right) 18-22$ or 25 , responsible for penicillinase production, were associated frequently with gentamicin or gentamicin and tetracycline resistance determinants.

Restriction analysis showed that plasmids with the same size and EcoRI restriction patterns as pBS283 and pBS983 were harboured by strains from all sources, except one (Avellino). The wide occurrence of such plasmids may indicate either spread from hospital to hospital of a strain bearing them, or a genetic transfer of these factors amongst different MRSA strains. Plasmids of similar mol. wt but conferring different resistance phenotypes showed different restriction profiles.

Characterisation of MRSA strains on the basis 
of the phenotype conferred by their largest plasmids has been proposed (El Solh et al., 1981; Townsend et al., 1985) because this is more informative than is plasmid-pattern analysis. However, we have found plasmids with the same mol. wt that conferred identical resistance characteristics but that showed different restriction profiles. Thus, restriction analysis of the largest plasmids provides an important additional tool not only to confirm the identity between plasmids, but also to establish different arrangements of the resistance determinants. Different restriction patterns in plasmids conferring apparently identical phenotypes may indicate the presence of genetic factors coding for undetected characteristics, not necessarily related to antibiotic resistance. It may be opportune, therefore, to broaden the study of the phenotypes conferred by the largest plasmids by examining various physiological characteristics and amplifying the number of antimicrobial agents tested. Townsend et al. (1984b, 1985), for example, showed that plasmids of mol. wt $\left(10^{6}\right)$ 15-22 can carry determinants for resistance to nucleic acid-binding compounds and to cationic surface active agents. We do not know if such determinants are also possessed by Italian isolates. Moreover, the results reported here are based only on curing experiments. To characterise plasmids completely, however, it would be necessary to transfer them to a recipient strain; experiments of this type are being performed in our laboratory at present.

Analysis of restriction patterns showed that plasmids with different profiles frequently shared one or more fragments. This may suggest that staphylococcal plasmids have originated from frequent rearrangements of a few resistance determinants. Various authors (Murphy and Novick, 1980; Novick et al., 1981) have demonstrated that recombination can occur between plasmids and give rise to the genetic versatility of $S$. aureus. Frequent transposition of plasmid genes to or from the chromosome can also occur (Novick et al., 1979; Phillips and Novick, 1979; Kahn and Novick, 1980). This may explain the recent isolation of multiresistant strains that are plasmid-free. In these strains all the resistance determinants must have been integrated in the chromosome. Such integration probably leads to a stabilisation of the resistance determinants (Lacey, 1984).

MRSA isolated in Brescia and the other five towns carried also smaller plasmids that encoded resistance to tetracycline or chloramphenicol. These plasmids appeared to be similar to those isolated in several countries (Lacey, 1975; Dowd et al., 1983; Gillespie et al., 1984; Lyon et al., 1984).
In some strains, tetracycline resistance was associated with larger plasmids of mol. wt $\left(10^{6}\right) 18-22$ or 25 and was frequently present on two different plasmids simultaneously, possibly in a transitory state. All the isolates resistant to chloramphenicol harboured the $2.6 \times 10^{6}-\mathrm{mol}$. wt plasmid that seems to be, therefore, the only one responsible for this phenotype.

Erythromycin resistance was often encoded on a plasmid of mol. wt $1.65 \times 10^{6}$. This observation is in accordance with those of several authors (Iordanescu, 1976; Horinouchi and Weisblum, 1980; Dyke and Noble, 1984; Weisblum, 1985) who have reported the resistance to erythromycin associated with small plasmids; other authors have demonstrated this trait as part of a penicillinase plasmid (Novick and Bouanchaud, 1971) or present on the chromosome (Kayser et al., 1976). Thus, the erythromycin resistance determinant may be associated with different sites of bacterial DNA. Two transposons responsible for macrolide resistance have been described (Novick et al., 1979; Phillips and Novick, 1979).

Small, cryptic, plasmids of mol. wt $\left(10^{6}\right) 1$ or 2 were found frequently. Other authors have described the isolation of small plasmids with no attributable function (Gillespie et al., 1984; Lyon et al., 1984). These plasmids are probably responsible for important accessory functions but could not be associated with resistance to any of the antimicrobial agents tested.

Plasmids coding for gentamicin resistance have been described (Wood et al., 1977; Jaffe et al., 1980; Townsend et al., 1984a) but, in Italian isolates, gentamicin resistance was often chromosomally encoded. In some isolates the gentamicin-resistance determinant was plasmid encoded and since the genes coding for gentamicin resistance have been described on a transposon (Lyon et al., 1984; Townsend et al., 1984b), it is possible that in Italian strains they have undergone transposition on to the chromosome, as observed by Kayser (1976).

In summary, isolates of multiresistant $S$. aureus often exhibit similar plasmid patterns, but restriction enzyme analysis has revealed differences between the largest plasmids. Further studies are required to establish whether different plasmids have a different origin or derive from rearrangement of a few resistance determinants.

We are grateful to Dr Kaye Wachsmuth for providing control strains and useful suggestions and to Professors C. Chezzi, A. Guarino, A. La Manna, P. Martinetto, G. Satta for kindly supplying clinical isolates. This work was supported by the Consiglio Nazionale delle Ricerche (Control of Infectious Diseases). 


\section{REFERENCES}

Andreoni O, Andreoni S, Molinari G L 1985 Multiresistenza antibiotica di batteri del genere Staphylococcus. Proceedings of the XIV Congresso Nazionale della Societá Italiana di Chemioterapia, Milan.

Asheshov E H 1966 Loss of antibiotic resistance in Staphylococcus aureus resulting from growth at high temperature. Journal of General Microbiology 42: 403-410

Baird-Parker A C, Hill L R, Kloos W E, Kocur M, Oeding P, Schleifer K H 1976 Identification of staphylococci. International Journal of Systematic Bacteriology 26: 333-334.

Bauer A W, Kirby W M, Sherris J C, Turk M 1966 Antibiotic susceptibility testing by a standardized single disk method. American Journal of Clinical Pathology 45:493-496.

Birnboim H C, Doly J 1979 A rapid alkaline extraction procedure for screening recombinant plasmid DNA. Nucleic Acid Research 7:1513-1523.

Bouanchaud D H, Scavizzi M R, Chabbert Y A 1968 Elimination by ethidium bromide of antibiotic resistance in enterobacteria and staphylococci. Journal of General Microbiology 54:417-425

Dowd G, Cafferkey M, Dougan G 1983 Gentamicin and methicillin resistant Staphylococcus aureus in Dublin Hospitals: molecular studies. Journal of Medical Microbiology 16: $129-138$.

Dunkle L M, Sippel C J 1984 Rapid microprocedure for extraction of plasmid DNA from Staphylococcus aureus. Journal of Infectious Diseases 149:921-923.

Dyke K G H, Noble W C 1984 Plasmids of phage-group II Staphylococcus aureus. Journal of Medical Microbiology 17:325-334.

E1 Solh N, Fouace J M, Pillet J, Chabbert Y A 1981 PlasmidDNA content of multiresistant Staphylococcus aureus strains. Annales de Microbiologie, Institut Pasteur 132 B : 131156.

Giamarellou H, Papapetropoulou M, Daikos G K 1981 Methicillin resistant Straphylococcus aureus infections during 1978-1979: clinical and bacteriologic observations. Journal of Antimicrobial Chemotherapy 7:649-655.

Gillespie M T, May J W, Skurray R A 1984 Antibiotic susceptibilities and plasmid profiles of nosocomial methicillin-resistant Staphylococcus aureus : a restrospective study. Journal of Medical Microbiology 17:295-310.

Horinouchi S, Weisblum B 1980 Post-transcriptional modification of mRNA conformation: mechanism that regulates erythromycin-induced resistance. Proceedings of the $\mathrm{Na}$ tional Academy of Sciences, USA 77:7079-7083.

Iordănescu S 1976 Three distinct plasmids originating in the same Staphylococcus aureus strain. Archives Roumaines de Pathologie Experimentale et de Microbiologie. 35:111-118.

Jaffe H W, Sweeney H M, Nathan C, Weinstein R A, Kabins S A, Cohen S 1980 Identity and interspecific transfer of gentamicin-resistance plasmids in Staphylococcus aureus and Staphylococcus epidermidis. Journal of Infectious Diseases $141,6: 738-747$.

Kayser F H 1976 Aminoglycoside-phosphorylating enzymes specified either by plasmid or chromosomal genes in Staphylococcus aureus and Staphylococcus epidermidis. Abstract No. 204, 16th Interscience Conference on Antimicrobial Agents and Chemotherapy, Chicago.

Kayser F H, Wüst J, Santanam P 1976 Genetic and molecular characterization of resistance determinants in methicillinresistant Staphylococcus aureus. Journal of Medical Microbi$\operatorname{ology} 9$ : 137-148.

Khan S A, Novick R P 1980 Terminal nucleotide sequences of Tn 551, a transposon specifying erythromycin resistance in
Staphylococcus aureus: homology with Tn3. Plasmid 4: 148154.

Kirby W M M 1984 Vancomycin therapy of severe staphylococcal infections. Journal of Antimicrobial Chemotherapy 14 Suppl D: 73-78.

Lacey R W 1975 Antibiotic resistance plasmids of Staphylococcus aureus and their clinical importance. Bacteriological Reviews 39: 1-32.

Lacey R W 1984 Antibiotic resistance in Staphylococcus aureus and streptococci. British Medical Bulletin 40:77-83.

Lacey R W, Keyworth N, Lincoln C 1984 Staphylococci in the U.K.: a review. Journal of Antimicrobial Chemotherapy 14 Suppl D:19-25.

Lyon B R, May J W, Skurray R A 1983 Analysis of plasmids in nosocomial strains of multiple-antibiotic-resistant Staphylococcus aureus. Antimicrobial Agents and Chemotherapy 23:817-826.

Lyon B R, Iuorio J L, May J W, Skurray R A 1984 Molecular epidemiology of multiresistant Staphylococcus aureus in Australian Hospitals. Journal of Medical Microbiology 17:79-89.

Murphy E, Novick R P 1980 Site-specific recombination between plasmids of Staphylococcus aureus. Journal of Bacteriology 141 : 316-326.

Novick R P, Bouanchaud D 1971 Extrachromosomal nature of drug resistance in Staphylococcus aureus. Annals of the New York Academy of Science 182:279-294.

Novick R P, Edelman I, Schwesinger M D, Gruss A D, Swanson E C, Pattee P A 1979 Genetic translocation in Staphylococcus aureus. Proceedings of the National Academy of Sciences USA 76:400-404.

Novick R P, Iordanescu S, Surdeanu M, Edelman I 1981 Transduction-related cointegrate formation between staphylococcal plasmids: a new type of site-specific recombination. Plasmid 6:159-172.

Phillips S, Novick R P 1979 Tn554 - a site-specific repressorcontrolled transposon in Staphylococcus aureus. Nature 278: $476-478$.

Shanson D C 1981 Antibiotic resistant Staphylococcus aureus. Journal of Hospital Infection 2:11-36.

Schito G C 1985 Meticillino-resistenza e problemi di terapia. Proceedings of the XIV Congresso Nazionale della Societá Italiana di Chemioterapia, Milan.

Townsend D E, Ashdown N, Greed L C, Grubb W B 1984a Analysis of plasmids mediating gentamicin resistance in methicillin-resistant Staphylococcus aureus. Journal of Antimicrobial Chemotherapy 13:347-352.

Townsend D E, Ashdown N, Greed L C, Grubb W B $1984 b$ Transposition of gentamicin resistance to staphylococcal plasmids encoding resistance to cationic agents. Journal of Antimicrobial Chemotherapy 14:115-124.

Townsend D E, Ashdown N, Momoh M, Grubb W B 1985 Distribution of plasmid-borne resistance to nucleic acid binding compounds in methicillin-resistant Staphylococcus aureus. Journal of Antimicrobial Chemotherapy 15:417-434.

Weisblum B 1985 Inducible resistance to macrolides, lincosamides and streptogramin type $B$ antibiotics: the resistance phenotype, its biological diversity, and structural elements that regulate expression. Journal of Antimicrobial Chemotherapy 16 Suppl A : 63-90.

Wenzel R P 1982 The emergence of methicillin-resistant Staphylococcus aureus. Annals of Internal Medicine 97:440442.

Wood D O, Carter M J, Best G K 1977 Plasmid-mediated resistance to gentamicin in Staphylococcus aureus. Antimicrobial Agents and Chemotherapy 12:513-517. 